\title{
Animal Husbandry Information Sources and Vocational Preferences of a Re-Settled Tribal Community
}

\author{
P. Reeja George*, G. Radhika**, Shibu Simon* and Rejani Kesavan* \\ *Department of Veterinary and Animal Husbandry Extension, **Department of Animal \\ Breeding and Genetics, College of Veterinary and Animal Sciences, \\ Pookot, Lakkidi P.O Wayanad, Kerala, India \\ *E-mail: reejageorgep@yahoo.co.in
}

KEYWORDS Animal Husbandry. Information Sources. Tribe. Vocational Preferences

\begin{abstract}
The present study was conducted in a tribal rehabilitated area, which is located in Wayanad district. The study investigated the sources of animal husbandry information as well as the animal husbandry vocational preferences of members of this area. The results of the study indicate that nearly 40per cent of the population came in the categories of no education and lower primary education. The monthly income of nearly one third of the families was a meager Rs.500 or below. The findings of the study also shed light on the meager use of mass media such as T.V, Radio and newspapers. In this traditional social system as is expected, interpersonal relationships are indicated as the source of information sometimes used (Self Help Groups). More than eighty percent of families were interested in taking up some kind of animal husbandry activity. This result points to a favorable attitude on the part of these families towards A.H enterprises. In this context it would be worth while to explore the feasibility of such enterprises in the study area.
\end{abstract}

\section{INTRODUCTION}

The scheduled tribes according to the 1991 census account for 67.76 million people and this represents $8.08 \%$ of the country's population. In Kerala, Wayanad district has the highest percentage of tribal population. Slightly over $17 \%$ of the population in the district is scheduled tribe, of which $50.09 \%$ are females. It is in this context that investigations into tribal area activities and remedial measures to improve their living conditions assume significance.

The present study was conducted in a tribal rehabilitated area, Suandagiri rehabilitated area which is located in Pozhuthana panchayat of Wayanad district, in the Southern most state of Kerala. The study investigated the sources of animal husbandry information of members of various tribes in a re settled area as well as their vocational preferences.

\section{METHODOLOGY}

The study was conducted using the census method of complete enumeration of 413 tribal houses in the tribal rehabilitated area of Sugandagiri located in Pozhuthana panchayat of Wayanad district in Kerala. A pre tested well structured interview schedule was developed. The interview schedule was prepared in English and carefully translated into the respondent's mother tongue to fit into their level of understanding. The interview schedule was pre- tested in a non sampling area and needed changes were made before the final administration. Data were collected during the month January and February of 2006. The respondents were personally contacted and rapport established to get unbiased information.

\section{RESULTSAND DISCUSSION}

\section{a. Socio-economic Profile of Respondents}

The results of the study indicate that nearly $40 \%$ of the population came in the categories of no education and lower primary education. This figure represents just less than half of the adults in the area understudy. However interaction with these individuals revealed that most of them could neither read nor write. Availability of latrine, type of roof and walls of home, were the variables which used in this study to determine the quality of life of the sample population.

Home condition has been reported as an important variable influencing the learning outcome of children (George and Domi 2002). The authors further opined that the living conditions, facilities and basic infra structure play an important role in the education, health and attitude of 
children. Results of the present investigation revealed that more than 55 per cent of respondents in the study area lived in makeshift houses without any walls and just above 46 per cent used grass as the roofing material. These figures are much higher than those reported by George and Domi (2002) in their study of fisher folk in Trivandrum district of the state where 5.45 percent lived in huts. The living conditions of these families is dismal keeping in mind the severe weather conditions in Wayanad in winter as well as in monsoon.

An alarming 71 per cent of respondents were using unhygienic pit latrines while nearly 30 per cent did not have access to even this facility This is much higher than that observed by George and Domi (2002) who observed that nearly 46 percent of fisher folk did not have separate latrine facilities.

The monthly income of nearly one third of the families was a meager Rs.500 or below. Nearly half of the families reported that their family monthly income was between Rs. 500 to Rs. 1000 . Ajithkumar and Sreekumar (1996) reported that the average annual income of forty eight per cent of dairy farmers in Thrissur district was above Rs 5000. Narayana (2005) observed that the below poverty line census of the rural development department of the Government of Kerala which has estimated the proportion of poor living in each district indicated that this proportion was considerably higher in Wayanad district $(50 \%)$ compared to the state average of 37 per cent. Narayana (2005) also reported that the annual per capita income of 43 per cent of households in Kotathara panchayat of Wayanad district was Rs 6743. George and Domi (2002) reported that the annual income of 43.55 per cent of fisher folk in Wayanad district was below Rs 5000. Parents' position in the hierarchy of relations is an important aspect of socio economic background because it helps to develop personality traits in children that correspond to distinct class cultures and these personality traits play a major role in determining a child's success in gaining higher incomes in future. (Bowel 1972). Thomas (1998) also observed that though education had an important role in facilitating upward mobility and achieving equality in society, it was hindered by the operation of family background variables. Keeping in mind these observations it is of at most necessity to explore suitable income generating activities among the tribal people of this rehabilitated area in order to improve their living conditions.

\section{b. Animal Husbandry Information Sources}

Table 1 gives details of the Animal husbandry information sources of the respondents of the study. An interesting finding is that the highest percentage $(26.63 \%)$ of persons sometimes sought information from the Kudumbasree or Neighborhood Self Help Groups of the State poverty eradication mission. The findings of the study also shed light on the meager use of mass media such as T.V, Radio and Newspapers. In this traditional social system as is expected, interpersonal relationships are indicated as the source of information sometimes used (Self Help Groups). This findings could be a stepping stone for further activity in strengthening the existing groups in the area. Future action can be channalized through these groups as well. The fact that mass media such as TV radio and Newspapers are not used by a significant majority of the population could be due to non-availability of the same. If so, some steps in this direction could be useful in helping establish a bonding between this community and the outside world.

\section{c. Preference for Animal Husbandry Vocations}

More than eighty percent of families were interested in taking up some kind of animal husbandry self employment activity. This result

Table 1: Animal husbandry information sources of the respondents of the study $(n=413)$

\begin{tabular}{|c|c|c|c|c|c|c|c|c|c|c|c|c|}
\hline \multirow{2}{*}{$\begin{array}{l}\text { Media } \\
\text { Frequency of usage }\end{array}$} & \multicolumn{2}{|c|}{$\begin{array}{l}\text { Radio } \\
\text { T.V }\end{array}$} & \multicolumn{2}{|c|}{$\begin{array}{c}\text { News- } \\
\text { papers }\end{array}$} & \multicolumn{2}{|c|}{$\begin{array}{c}\text { Vet. } \\
\text { hospital }\end{array}$} & \multicolumn{2}{|c|}{$\begin{array}{c}\text { Neighbourhood } \\
\text { groups }\end{array}$} & \multicolumn{2}{|c|}{$\begin{array}{c}\text { Tribal } \\
\text { class }\end{array}$} & \multicolumn{2}{|c|}{ Krishibhavan } \\
\hline & $f$ & $\%$ & $f$ & $\%$ & $f$ & $\%$ & $f$ & $\%$ & $f$ & $\%$ & $f$ & $\%$ \\
\hline Always & 42 & 10.16 & 13 & 3.14 & 8 & 1.93 & 17 & 4.11 & 6 & 1.45 & 2 & 0.48 \\
\hline Sometimes & 100 & 24.21 & 8 & 6.77 & 19 & 4. 60 & 110 & 26.63 & 12 & 0.24 & 16 & 3.87 \\
\hline $\begin{array}{l}\text { Whenever } \\
\text { there is time }\end{array}$ & 26 & 6.29 & 4 & 0.24 & 10 & 2.42 & 11 & 2.66 & 2 & 4.60 & 2 & 0.48 \\
\hline Never & 245 & 59.32 & 370 & 89.95 & 376 & 91.04 & 275 & 66.58 & 393 & 95.25 & 395 & 95.60 \\
\hline
\end{tabular}


points to a favorable attitude on the part of these families towards A.H enterprises. In this context it would be worth while to explore the feasibility of such enterprises in the study area through participatory exercises. Out of 367 families who were interested in taking up animal husbandry enterprises, 275 of them that is nearly three quarters $(74.9 \%)$ ranked cattle rearing as their first choice, while $9 \%$ ranked goat keeping as their first choice. Just over $12 \%$ ranked poultry keeping as their first choice and a minority $3.5 \%$ ranked rabbitary as their first choice. More exposure to other enterprises could help in averting possible misconceptions about goat keeping, poultry rearing and rabbitary among these people.

The findings of the study shed light on the positive attitude of many of the rehabilitated families towards taking up animal husbandry vocations in order to improve their livelihood. Positive support from other agencies concerned could help promote such ventures in order to sustain these communities.

\section{REFERENCES}

Ajithkumar G, Sreekumar D 1996. Profile analysis of owners of infertile cows in Mannuthy area of Thrissur district of Kerala. J Vet and A Sci, 27: 158-159.

Bowel S 1972. Schooling and inequality from generation to generation. J of Political Economy, 80(3): S219-S51

George MK, Domi J 2002. Residual illiteracy in a costal village: Poovar village of Thiruvanathapuram district. Discussion Paper No 45. Centre for Development Studies, Thiruvanathapuram, Kerala, India.

Narayana D 2005. Perception, poverty and health. Paper Presented at CICRED. Seminar on Mortality as a Determinant and Consequence of Poverty and Hunger. Centre for Development Studies, February 22-25, 2005, Thiruvanathapuram Kerala, India.

Thomas J 1998. Education and Economic Development. New Delhi: Anmol Publications Pvt. Ltd. 